Cahiers $d u$ MONDE RUSSE

\section{Cahiers du monde russe}

Russie - Empire russe - Union soviétique et États indépendants

45/1-2 | 2004

Stratégies impériales

\title{
Proconsular ambitions on the Chinese border
}

Governor general iakobi's proposal of war on China

John P. LeDonne

\section{(2) OpenEdition}

1 Journals

Édition électronique

URL : https://journals.openedition.org/monderusse/8678

DOI : 10.4000/monderusse. 8678

ISSN : $1777-5388$

Éditeur

Éditions de l'EHESS

Édition imprimée

Date de publication : 1 janvier 2004

Pagination : 31-60

ISBN : 2-7132-2008-4

ISSN : $1252-6576$

Référence électronique

John P. LeDonne, "Proconsular ambitions on the Chinese border », Cahiers du monde russe [En ligne], 45/1-2 | 2004, mis en ligne le 01 janvier 2007, consulté le 04 septembre 2022. URL : http://

journals.openedition.org/monderusse/8678; DOI : https://doi.org/10.4000/monderusse.8678 
chercher : repérer : avancer

Cet article est disponible en ligne à l'adresse :

http://www.cairn.info/article.php?ID REVUE=CMR\&ID NUMPUBLIE=CMR 451\&ID ARTICLE=CMR 4510031

\title{
Proconsular ambitions on the Chinese border. Governor general iakobi's proposal of war on China
}

\author{
par JOHN P. LEDONNE
}

\section{| Editions de l'EHESS | Cahiers du monde russe}

\author{
2004/1-2 - Vol 45 \\ ISSN 1252-6576 | ISBN 2713220084 | pages 31 à 60
}

Pour citer cet article :

- LEDONNE J., Proconsular ambitions on the Chinese border. Governor general iakobi's proposal of war on China, Cahiers du monde russe 2004/ 1-2, Vol 45, p. 31-60.

Distribution électronique Cairn pour les Editions de l'EHESS.

(C) Editions de l'EHESS. Tous droits réservés pour tous pays.

La reproduction ou représentation de cet article, notamment par photocopie, n'est autorisée que dans les limites des conditions générales d'utilisation du site ou, le cas échéant, des conditions générales de la licence souscrite par votre établissement. Toute autre reproduction ou représentation, en tout ou partie, sous quelque forme et de quelque manière que ce soit, est interdite sauf accord préalable et écrit de l'éditeur, en dehors des cas prévus par la législation en vigueur en France. Il est précisé que son stockage dans une base de données est également interdit. 


\title{
PROCONSULAR AMBITIONS ON THE CHINESE BORDER
}

\author{
Governor general Iakobi's proposal \\ of war on China
}

The great event in the history of Russia's relations with China before $1858^{1}$ was the Treaty of Nerchinsk (1689), by which Russia was forced to give up its claims on the Amur valley and to retreat to the inner periphery of the Heartland along the Iablonoi and Stanovoi mountains. ${ }^{2}$ The Russians' vision of Siberia - and indeed of the Heartland in general - was a perception of river valleys and sea basins, in which rivers - both in summer and especially in winter, when they froze over - provided the only tolerably efficient means of transporting goods and equipment. Great rivers also led to great oceans - the Siberian rivers discharged into the (largely useless) Arctic Ocean, and the Amur led to the Sea of Okhotsk and, beyond it, to the Pacific. The expansion of the Muscovite core into Siberia had been a logical consequence of the disintegration of the Mongol khanates which had succeeded the Chingissid empire of the thirteenth century: the conquest of the Siberian khanate followed within thirty years that of the khanates of Kazan and Astrakhan, but the absorption of the last khanate would have to wait until 1783, when the Crimea was annexed. The conquest of Siberia - hopping from one river valley to another - was largely fueled by the fur trade in sables, foxes, beavers, and squirrels which stopped along the ecological boundary between Siberia and Mongolia, where sparse forests and

1. The date of the Treaty or Aigun, which gave Russia the left bank of the Amur River and joint control of the Maritime Province, at the southern tip of which Governor General Nikolai Muravev founded Vladivostok in 1860.

2. For the concept of Heartland, see J. LeDonne, The Russian empire and the world, 1700-1917. The geopolitics of expansion and containment (New York, 1997): 1-3. 
insignificant snowfall rendered the country unattractive to trappers. ${ }^{3}$ If the fur trade - the systematic destruction of the fur-bearing animal kingdom for profit was to continue, it would have to expand beyond the sea to the Aleutian Islands and Alaska with their abundant supply of sea otters, but those regions could be reached with difficulty from the port of Okhotsk, itself nearly cut off from Siberia proper by the Dzhugzhur range, the Heartland's periphery.

The loss of access to the Amur valley was resented, and the question arose from time to time whether Russia should not take the risk of a war on the Celestial Empire to force a re-negotiation of the Treaty of Nerchinsk for the purpose of gaining the right of free navigation on the river. The instruction given in 1725 to Savva Vladislavich (Raguzinskii), who headed an embassy to China, did not raise the Amur issue, because its specific purpose was to reach an agreement on the Siberian-Mongolian border. That agreement was incorporated into the Treaty of Kiakhta (1727), which also regulated the Russo-Chinese trade. ${ }^{4}$ Russian interest in Mongolia was not merely a consequence of losing access to the Amur. It was also dictated by major convulsions in the Mongol world to which neither the Chinese nor the Russians could remain indifferent. A Tungussic tribe that called itself Manchus produced in the 1620s an ambitious leadership which quickly developed a power base in the valley of the Sungari and gained control of Peking (Beijing) in 1644, establishing a new dynasty that would last until 1911. At the same time, however, the Western Mongols consisting of four major groups formed a political confederation for the purpose of reuniting the Mongol clans..$^{5}$ If this so-called Zunghar confederation succeeded in bringing in the Eastern Mongols (Khalkhas) as well, it would create a power structure strong enough to rival the Manchus and threaten their hold on China: nearly four hundred years earlier, the Mongols had founded their own dynasty in China (1260-1368). Thus, the ambitions of the Western Mongols constituted a threat to both Manchus and Chinese and contributed to the strengthening of Manchu rule in China. They also threatened the advance of Russian settlements in the Baraba and Kunlunda steppes between the Irtysh and the $\mathrm{Ob}$ and in the Koibal steppe flanking the Enisei, where Tomsk, Minusinsk and Krasnoiarsk were already developing into major outposts. Last but not least, they were also bound to clash with the Russians' penetration of the Altai massif rumored to abound in mineral wealth.

3. The two major works are R. Fisher, The Russian fur trade 1550-1700 (Berkeley, 1943) and J. Martin, Treasure of the land of darkness: The fur trade and its significance for medieval Russia (Cambridge, 1986). See also J. Gibson, Feeding the Russian fur trade (Madison, 1969).

4. The negotiations are treated extensively in N. N. Bantysh-Kamenskii, Diplomaticheskoe sobranie del mezhdu Rossiiskim i Kitaiskim gosudarstvami s 1619 po 1792-i god (Kazan, 1882): 132-164, 341-373. For an analysis of the boundary treaty see J. Prescott, Map of mainland Asia by treaty (Melbourne, 1975): 18-25. See also E. Silin, Kiakhta V XVIII veke (Irkutsk, 1947): 23-38. The book is devoted to the Russo-Chinese trade in the eighteenth century.

5. Th. Barfield, The perilous frontier. Nomadic empires and China (Oxford, 1989): 278-279. On the Western and Eastern Mongols see G. Potanin, Ocherki Severo-Zapadnoi Mongolii, 4 vol. (Petersburg, 1881-1883), here 2: 19-46. The third volume, part 1 of E. Grum-Grzhimailo, Zapadnaia Mongoliia i Uriankhaiskii krai, 3 vol.(Petersburg, 1914-1930) is entirely devoted to them. 
Before we turn to the geopolitical situation in the middle of the eighteenth century, it will be useful to examine the characteristic features of Mongolia's physical geography, without which the territorial context of Iakobi's proposal would be lost. The approximate physical boundary of present-day Outer Mongolia follows in the west the Mongolian Altai which slowly descends to form the Gobi Altai, then follows the alignment of the Gobi Desert - "one of the most awful regions on our planet" - to the Great Kinghan, the outer periphery of the Heartland. It then turns northeast to meet the old border demarcated after 1727 running along the southern crests of the Saian and Altai massif, the watershed between the basin of the Selenga on the one hand and that of the Ob and Enisei on the other. It meets again the Mongolian Altai near Mount Kuiten (Youyi Feng) at an altitude of 4,355 meters. The basin of the Selenga - its tributaries, notably the Orkhon, descend from the Khangai plateau overlooking the lower ranges of the Mongolian and Gobi Altai to the south - was the land of the Eastern Mongols. The Selenga flows into Lake Baikal, from which the Angara, on which Irkutsk is located, begins its long northward curve to meet the Enisei which, like the Ob, its neighbour to the west, empties into the Arctic Ocean ("the Northern Sea").

This central part of Mongolia, the most fit for human settlement with its abundant meadows and pastures, thus belonged to the Siberian hydrographic network draining the waters of all the rivers descending from the Khangai, the Altai, the Saian, and even the Kazakh upland and the eastern slopes of the Urals, toward the Arctic Ocean. Further to the west, the Altai and Saian Mountains, together with the triangular zone formed by the Mongolian Altai and the Borokhovo chain to the south, were the lands of the Zunghars who, in the winter, took their flocks down into the open northern steppes, where they encountered the Russians, and into the Kazakh steppe through the "Zungharian Gate," where they encountered the Kazakhs, a Turkic people with which they were in permanent conflict over pastures. The most important area of contention was Lake Zaisan, where the Black Irtysh descending from the Mongolian Altai fills a large trough through which it exits to become the White Irtysh, or simply the Irtysh, flowing north toward Tobolsk, the capital of Siberia, and its confluence with the Ob. Such was the geographical context in which Iakobi's proposal must be placed. Before turning to it, let us examine the relationship between Russians, Mongols, and Manchus-Chinese which formed its immediate background.

Our story begins with the arrival of Bartholomew Iakobi (Jacobi, 1687-1769) the governor general's father - in Selenginsk in 1740. Iakobi was a Pole who had served in Russia's Turkish campaign of 1711, was stationed in Poland thereafter,

6. Iu. Rerikh (G. Roerich), Tibet i Tsentral'naia Aziia (Samara, 1999): 291. On the geography of Mongolia see Th. Barfield, The perilous frontier..., op. cit.: 16-18 and C. Bawden, The modern history of Mongolia (London, 1968): 6-7, 19-21. 
fought and remained in northern Persia from 1722 to 1731 , served in the Polish expedition of 1733-1735 to overthrow the newly elected Polish king, and completed his active military career in the Turkish war of 1736-1739. In 1740, he was promoted to brigadier general (brigadir) and sent to Selenginsk near the Mongolian border to take up, under the overall command of the Siberian governor residing in Tobolsk, the perennial issues - trade and fugitives - plaguing RussoChinese relations along the interminable and largely undefended border between the two empires. He remained in Selenginsk for 28 years, retiring shortly before his death with a promotion to lieutenant general. ${ }^{7}$

The Russian advance across Siberia and the establishment of fortified outposts along the foothills of the Altai and Saian massifs and, beyond Lake Baikal, in the basin of the Shilka which merges with the Argun to form the Amur River, paralleled the growth of Manchu power in the valley of the Sungari, the founding of a Manchu dynasty in Peking in 1644, and the imposition of Manchu overlordship over the Khalkhas. As a result, a vast frontier came into being between the two empires, an indefinite and turbulent frontier requiring the urgent demarcation of a clear boundary to prevent disputes between the two core areas of Russia and China from degenerating into open hostilities.

Russia's relations with the Mongols in the frontier and with China helped the Russians shape a geographical perception of the limits of their Siberian empire. In the west, the emergence of the Zunghar confederation in the 1680s under the leadership of Galdan Boshugtu (1671-1697), who came from Kobdo, a settlement in the triangle formed by the Altai and the Mongolian Altai, paved the way for the expansion of those Mongols eastwards into the land of the Khalkhas, northward into the Altai and the Baraba steppe, and westward into the grazing lands of the Kazakhs of the Large and Middle Horde. A consequence was a standing jurisdictional rivalry with the Russians over the right to collect the fur tribute (iasak) from isolated tribes. A disputed area at the beginning of the eighteenth century was the salt lakes of the Baraba steppe from which both the Russians in Siberia and the Zunghars derived their supply of salt, the latter not only for themselves alone but also for their enormous herds of cattle. ${ }^{8}$

After 1708, when Siberia became a province (guberniia) and was placed under a governor who resided in Tobolsk, "the capital of Siberia," beginning in 1711, the Russians became more insistent in their claim to tax the so-called Baraba Tatars and other clusters of nomads, notably the Kirgiz (also called Black Kirgiz) of the Krasnoiarsk and Eniseisk region, over whom the Zunghars also claimed jurisdiction. ${ }^{9}$ Early in 1715 , Governor Matvei Gagarin informed the Zunghar leader

7. A short biography is in Russkii biograficheskii slovar' (RBS), 25 vol. (Petersburg, 1896-1918), here 25 (1913): 55-56.

8. Th. Barfield, The perilous frontier..., op. cit.: 282-284; M. Courant, L'Asie centrale aux XVII et XVIII siècles. Empire kalmuk ou empire mandchou ?(Paris, 1912): 35-40, 50-53; and M. Rossabi, China and Inner Asia. from 1368 to the present day (London, 1975): 122-123, 143.

9. On these Kirgiz, see John and Robert Michell, eds, The Russians in Central Asia (London, 1865): 89-94. 
(khuntaishi), Tsewang Rabtan, of his intention to send an expedition along the Irtysh into Zunghar-controlled territory for the purpose of finding a way to Yarkend in Kashgaria (also known at the time as Little Bukhara), rumored to abound in gold, adding that the Russians had no hostile intentions. He also used the opportunity to give the khuntaishi his views on the extent of Russian territorial claims in Siberia. Russia was already established on the Irtysh, the Ob, the Enisei and the Lena, said Gagarin. These rivers flowed into the Arctic Ocean, and Russia claimed jurisdiction over their entire course. In other words, Siberia meant the entire basin of the Arctic Ocean - if by the basin of a sea we mean the basin of all the rivers flowing into it - for Gagarin added that Russia also claimed the mountainous areas containing their headwaters. ${ }^{10}$ In other words, the governor assumed that the Black Irtysh to the Mongolian Altai (now part of China's Sinkiang - Xinjiang province), the Altai massif (the headwaters of the $\mathrm{Ob}$, as well as the high valley of the upper Enisei between the Saian and the Tannu Ola - the future Tuva autonomous republic of the Soviet Union acquired in 1944) were Russian possessions.

This perception of geographical space as consisting of river basins came naturally to a member of the imperial elite: Muscovy had grown by invading river basins - the Volga, the Dniepr, the Northern and Western Dvinas - and these rivers formed so many arteries, of sea basins - the Caspian, the Black Sea, the Baltic, and the Barents Sea. If Russia proper straddled the basins of four seas, then Siberia was the basin of the Arctic Ocean. But this perception also had extensive implications with a direct bearing on the topic of this article. Gagarin's gaze did not extend beyond the Lena, which takes its source on a high ridge along the western coast of Lake Baikal, but the lake's basin offered challenging geopolitical perspectives, It was connected with the Enisei by the Angara but fed chiefly by the Selenga. Thus, this river, as well as its several tributaries irrigating the land of the Khalkhas, also belonged via Lake Baikal and the Angara to the basin of the Arctic Ocean. It followed from Gagarin's reasoning that the Russians could legitimately claim jurisdiction over the land of the Khalkhas or most of what is today Outer Mongolia. This is not idle speculation. The Senate's instruction to Raguzinskii ordered him to reject Chinese attempts to revise the Treaty of Nerchinsk by moving back the border from the Argun to Lake Baikal (and even to the Angara) and to insist that all rivers flowing into the Angara "and into Lake Baikal' must belong to the Russian empire. ${ }^{11}$ It is not clear whether the

10. The text of Gagarin's letter is in Mezhdunarodnye otnosheniia $V$ Tsentral'noi Azii, XVII-XVIII VV., 2 vol. (Moscow, 1989), here 1: 232-233. See also M. Bassin, "Russia between Europe and Asia: The ideological construction of geographical space," Slavic Review, 50 (1991): 1-17, and "Inventing Siberia: visions of the Russian empire in the early nineteenth century," American Historical Review, 96 (1991): 763-794.

11. Mezhdunarodnye otnosheniia...., op. cit.,1: 258-261, pt. 4. The text is slightly ambiguous. It reads: "the Angara River which they [the Chinese] claim as their border is within the Siberian province of Russia's dominions and it is at a great distance from the Argun [the border established by the Treaty of Nerchinsk]. Therefore, it cannot be the border with China, but all rivers which flow into it and into Lake Baikal remain on the right side ( $v$ pravoi storone) of 
geographical information at the Senate's disposal showed the implications of such a claim, ${ }^{12}$ but even if it did not, the Senate's position, which derived logically from Gagarin's assumptions, created a precedent for subsequently asserting jurisdiction over the land of the Khalkhas.

The most serious issue facing Iakobi - whose title was commandant of Selenginsk - and his superiors in Tobolsk, Governor Vasilii Miatlev (17521757) and Fedor Soimonov (1757-1763), was the fallout from the massive Manchu campaign to exterminate the Zunghars who, since the days of Galdan, had kept the northwest frontier of the Manchu empire in constant turmoil. Following the death of Khuntaishi Galdan Tsering in 1745, a succession struggle paralyzed the Zunghar leadership and created additional turmoil until Dawachi, a cousin of Galdan Tsering, was able to assert his authority in 1753. But not for long. His intransigent attitude toward the Manchus gave a rival, Amursana, an opportunity to challenge him for the leadership of the Zunghars. In the fall of 1754, Amursana deserted the Zunghars and offered his services to the Ch'ienlung (Qianlong) emperor (r. 1736-1795), the second and last great emperor of the Manchu dynasty. The defection convinced the emperor that the days of the Zunghar confederation were numbered. He welcomed Amursana, gave him a high rank and a command in one of the two armies sent against the Zunghars in the spring of 1757 from Uliasutai (Uliastay) and Hami. Dawachi was defeated, fled to Aksu in Kashgaria, where he was caught and turned over to the Manchus who kept him in Peking - this was often done with nomadic chieftains - as a potential claimant in a future succession struggle. But Amursana had his own agenda. He was disappointed by the Manchus' refusal to recognize him as Dawachi's successor, deserted them, and called on the Zunghars to rally around him in a last-ditch struggle against the invaders. ${ }^{13}$

This betrayal of the Manchu cause determined the emperor to destroy the Zunghar confederation. In 1756, Manchu-Chinese troops invaded Zungharia and forced Amursana to flee to the Kazakhs of the Middle Horde. Pursued into the Kazakh steppe, Amursana appealed in vain to the Russians for military aid, but was promised asylum. In July 1757, he arrived at Semipalatinsk on the Irtysh and was sent to Tobolsk, where he died of smallpox in October. Meanwhile a third of the

\footnotetext{
Russia's dominions." The right side of the Argun can only refer to the land to the west of the river on its left side - unless one looks at the map upside down, i.e., from Moscow, in which case the land west of the Argun to Lake Baikal becomes "the right side." The full instruction is in N. N. Bantysh-Kamenskii, Diplomaticheskoe sobranie..., op. cit.: 434-455.

12. For this, consult G. Cahen, Les cartes de la Sibérie au XVIII ${ }^{e}$ siècle. Essai de bibliographie critique (Paris, 1911)

13. Th. Barfield, The perilous frontier..., op. cit.: 292-294; M. Courant, L'Asie..., op. cit.: 100-106; M. Rossabi, China..., op. cit.: 147; and P. Perdue, "Military mobilization in seventeenth and eighteenth century China, Russia and Mongolia," Modern Asian Studies, 30 (1996): 757-793, here 767-768. See also B. Gurevich, Mezhdunarodnye otnosheniia $V$ Tsentral'noi Azii v XVII-pervoi polovine XIX v. (Moscow, 1979): 104-106, and for the Amursana phase of the conflict, I. Zlatkin, Istoriia Dzhungarskogo khanstva, 1635-1758, 2nd ed. (Moscow, 1983): 286-303. A general survey is in F. Bergholz, The partition of the steppe (New York, 1993): 378-404.
} 
approximately one million Zunghars was massacred, ${ }^{14}$ nearly half died of smallpox, and many of the others fled into Russian territory. The Manchu war machine did not stop there. In the spring of 1757, a Muslim rebellion broke out, and the campaign was extended into Kashgaria which was pacified at the end of 1759. By then, Manchu China had become the hegemon in Inner Asia, a position it would retain for half a century. ${ }^{15}$

But the long wars with the Zunghars had been expensive, and the Khalkha Mongols were made to bear the brunt of the war effort. The Manchus demanded the active participation of the Mongol princes in staffing the armies being sent so far away from the Chinese core - Uliasutai, the Manchu military headquarters in Western Mongolia was 1,600 miles from Peking, and Ili in the heart of Zunghar country, 3,300 miles away ${ }^{16}$ - and imposed heavy taxes on the nomads in the form of purchases of millions of sheep at low valuation. They also drafted large numbers of Mongols to supply horses and camels to transport provisions and equipment and to maintain the postal system. In other words, the Eastern Mongols were made responsible for the logistics of the war against the Western Mongols. The integration of Mongolia into the Manchu war economy was considerably aggravated by increasing exploitation by unscrupulous Chinese merchants who, in the absence of substantial Russian competition after 1728, when the Russian trade was restricted to Kiakhta, acquired a monopoly of Mongolia's internal trade. The resulting stresses brought about a rebellion in 1756 . The catalyst was the execution in Peking in the spring of a Mongol prince of the Chingissid imperial clan who was also the younger half-brother of the head (khutukhtu) of the Mongol Lamaist church. The khutukhtu was venerated as the incarnation of Mongol identity under Manchu rule, and the order to watch the execution made the humiliation even worse. The prince had been ordered to escort Amursana to Peking where it was suspected that the latter might defect, but had allowed him to escape. In Western Mongolia, another Chingissid prince who also served in the Manchu army rose in open revolt, but never sought to coordinate his operations with Amursana. In Khalkha country, there was widespread looting and burning of Chinese shops. The Manchus proceeded to crush the rebels "with a savagery exceeded only by the viciousness with which they were to depopulate Zungharia."17 The harsh repression, which did not stop at executing Chingissids if need be, created revulsion

14. P. Perdue, "Military mobilization...," art. cit. : 759. For an account of the losses from a Chinese source, see Mezhdunarodnye otnosheniia..., op. cit., 1: 222: 3/10 of the population exterminated ("died"), 4/10 died from smallpox, and 2/10 fled to Russia (leaving 1/10 unaccounted for). See also M. Courant, L'Asie..., op. cit.: 106-107, 112. Some details on Amursana's negotiations with the Russians and his death are in I. Zlatkin, "Russkie arkhivnye materialy ob Amursane," in Filologiia i istoriia Mongol'skikh narodov (Moscow 1958): 289-313. He was 35 at the time of his death.

15. For the Muslim insurrection in Kashgaria see M. Rossabi, China..., op.cit.: 148-149 and M. Courant, L'Asie..., op.cit.: 117-118, 123-124.

16. M. Rossabi, China..., op.cit.:162: 1,600 miles meant 83 days on foot, 3,300 miles 193 days.

17. C. Bawden, The modern history..., op. cit.: 126. 
and much disarray among the Mongol elite, and prompted an attempt to negotiate a transfer of allegiance to Russia. ${ }^{18}$

The Russians had been following the evolution of the Manchu-Zunghar conflict for a long time. They had been building forts along the Irtysh all the way to UstKamenogorsk on the approaches to Lake Zaisan and into the Altai massif to protect the gold mines taken over from the Demidov family in May 1747 by the Cabinet, the economic management office of the Romanov house. In 1744, these forts and redoubts and their small Cossack units were placed under the command of Major General Christian Kindermann, responsible to the governor of Siberia and the College of War in Petersburg. The following year, two regiments of infantry and three of dragoons together with 1,000 Iaik (Ural) Cossacks were sent to man those defensive positions. ${ }^{19}$

In 1756, as Manchu repression intensified, Zunghars and Khalkhas began to cross into Siberia in parties that became increasingly larger, thereby creating a quandary for the Russians who, in accordance with the treaties of Nerchinsk and Kiakhta, were required to return them. They had no intention of doing so, however, because they welcomed more nomads into their sparsely populated frontier zones or were ready to resettle them in other areas in want of population, where they would do the least harm. But the news received in February that 10,000 tents (iurty), or about 50,000 Mongols, wanted to cross raised much larger issues. It was not clear where such a large number of nomads would be transferred in order to avoid fights over pastures with other Mongols on the Russian side, but in October, the College of Foreign Affairs was willing to give them camping grounds between Selenginsk and Nerchinsk, i.e., in Transbaikalia facing the nearly empty eastern frontier with Mongolia. Iakobi was wary, however. Such a move might bring about a counter-move by the Manchus, and the Russians were not strong enough militarily. In addition, the Russians should wait until the position of the khutukhtu was known: his authority was such that the nomads' real intentions would remain unclear until he had spoken. In the meantime, they should build up their forces with regular units, Cossacks and artillery brought in from European Russia and stock up magazines in Selenginsk and Nerchinsk. The next step would be to take advantage of the Manchus' difficulties in Mongolia to demand the right of free navigation on the Amur, and if they refused, to send a naval expedition to the river's mouth, build forts on the southern banks of the river and in Khalkha country, and finally establish a protectorate in Mongolia to guarantee the Khalkhas the security of their pastures against Manchu incursions. ${ }^{20}$

18. Ibid.: 112-121, and by the same author, "The Mongol rebellion of 1756-57," Journal of Asian History, 2 (1968): 1-31.

19. For the network of fortresses and the deployment of troops in Siberia in the 1740 s, see "Materialy dlia istorii Sibiri. Sostoianie ukreplenii i voisk," Chteniia v imperatorskom obshchestve istorii i drevnostei Rossiiskikh pri Moskovskom Universitete (hereafter Chteniia), 264 vol. (Moscow, 1856-1918), here 4 (Oct.-Dec. 1866): 1-53. For the Cossack troops in particular, see Kazach 'i voiska Aziatskoi Rossii v XVIII-nachale XX veka (Moscow, 2000): 48-59.

20. G. Sychevskii, "Istoricheskaia zapiska o Kitaiskoi granitse (1846)," Chteniia, 2 (April-June 1875): 1-292, here 135-140. 
But events were moving faster than Iakobi anticipated. The Manchus' determination to bring to an end their interminable difficulties with the Zunghars may have taken the Russians by surprise. There was no time to wait for reinforcements from Russia. Iakobi then heard that the khutukhtu, annoyed by the execution of his half-brother, was contemplating transferring his allegiance to the "White (western) Tsar," as the Russian ruler was often called. It was expected that his decision would determine "the entire Mongol people" to follow suit, as well as the Daurs, a Tungussic people camping on both sides of the Amur. This would automatically give the Russians access to the river, and Chinese permission would no longer be needed. The khutukhtu and his people must be recognized as subjects of the empire even if they wished to remain in Mongolia, but in such a case, they must provide for their own defense until Russian forces were brought up to sufficient strength to face the Manchus, who were boasting of having 200,000 troops in the field against the Zunghars.

A comedy of errors followed. The Senate refused to take a stand pending further information on the khutukhtu's real intentions. The khutukhtu was browbeaten by the Manchus, who were well aware that contacts had been established with the Russians. Tensions were rising over the detention of Amursana. By the end of 1758, there would be reports that 12,000 ManchusChinese were within 70 kilometers of Semipalatinsk and another 60,000 poised against the Irtysh Line. The imperial government in Petersburg hesitated to commit itself. In January 1757, the College of Foreign Affairs ordered Miatlev to find out if the khutukhtu and his shabi ${ }^{21}$ wanted to settle in Siberia and if the Tushetu Khan - the leader of the most important of the four Khalkha khanates $^{22}$ - also wanted to defect. In the meantime, it gave him the green light to recognize the Mongols, as subjects of the empire if they chose to remain in Mongolia. The khutukhtu also hesitated, feeling closer to the Manchus-Chinese than to the Russians with whom he truly had nothing in common. His hesitation doomed all prospects of a change of allegiance but also cost him his life: the Manchus who suspected his loyalty, had him poisoned at the beginning of 1758 . They also ordered the execution of the Tushetu Khan and his top general for keeping contacts with the Russians, including Iakobi, who had travelled to Mongolia to gain a first-hand knowledge of the situation in the field. In the summer of 1757, a general meeting took place of khans and clan leaders in Urga, but in the absence of leadership by the khutukhtu, nothing was decided. The bonds with the Manchu dynasty were by then too strong, and the Khalkha aristocracy, no matter how irritated by the high-handedness of the Manchus, was not willing to risk its substantial privileges for an uncertain future under Russian overlordship.

21. The serfs of the khutukhtu and the nucleus of his wealth: C. Bawden, Modern history..., op. cit.: 69.

22. On the political organization of Mongolia, see N. DiCosmo, "Qing colonial administration in Inner Asia," The International History Review, 20 (1998): 287-309, here 300-303, and M. Veniukov, "Zabaikal'e i Khalka," Voennyi sbornik, 8 (1872): 193-230, here 218-219. 
Iakobi's and Miatlev's reports clearly show that relations with the Mongols were part of a larger program aimed at gaining navigation of the Amur. Indeed, Miatlev was of the opinion that supporting the secession of the Khalkhas would cut off the Manchu-Chinese army from its bases and enable Petersburg to dictate to Peking a revision of the Treaty of Nerchinsk. ${ }^{23}$ This must be kept in mind when we turn to an examination of the proposal by Iakobi's son to make war on China. In May 1732, the Senate had authorized a second "Kamchatka expedition" led by Captain Vitus Bering for the purpose of discovering islands between Kamchatka and America, surveying the coast between the mouth of the Uda and that of the Amur, and finding a better route between Lake Baikal and Okhotsk. ${ }^{24}$ In violation of the Treaty of Nerchinsk, the Russians remained engaged in the fur trade between the Uda and the Amur. In 1753, the newly appointed Miatlev was ordered to prepare another Kamchatka expedition, and he promptly reported that the most convenient way to reach the Pacific was by way of the Ingoda and the Amur. ${ }^{25}$ Since it could not be expected that the Manchus would give the Russians the right to navigate the Amur which flowed across their homeland in the north, an opportunity had to be found to compel them to concede that right. The disturbance in Mongolia provided such an opportunity but, as we saw, the Russians were unable to take advantage of it.

After 1760, the Manchu dynasty was at the height of its power, and with hegemony came unprecedented arrogance, of which the Russians quickly became aware when the Manchus closed the Kiakhta trade from 1762 to 1769 , in 17781780 , and from 1785 to $1792 .{ }^{26}$ That hegemony and the implantation of an imperial infrastructure in Mongolia and Eastern Turkestan neutralized potential attempts to rebel. By maintaining peace along the Russo-Chinese border, the Manchus precluded opportunities which the Russians might use against their rule. Their overwhelming power blocked any Russian intentions to force their hands in the matter of navigation on the Amur. Indeed, after 1765, the Russians shelved the issue for forty years. ${ }^{27}$

23. M. Pavlovsky, Chinese-Russian relations (New York, 1949): 32-33.

24. D. Lebedev, Ocherki po istorii geografii v Rossii 18 v. 1725-1800 gg. (Moscow, 1957): 190-197. A documentary collection is in Russkie ekspeditsii po izucheniiu severnoi chasti Tikhovogo Okeana v pervoi polovine XVIII veka. Sbornik dokumentov (Moscow, 1984): 111-281. See also G. Barratt, Russia in Pacific waters, 1715-1815: A survey of Russia's naval presence in the North and South Pacific (Vancouver and London, 1981): 16-41.

25. A portage on the Iablonoi chain connects the Khilok, a tributary of the Selenga, with the Ingoda, a tributary of the Shilka-Amur. It is part of the watershed separating the basin of the Arctic Ocean from that of the Pacific. On the Siberian river network and portages, see R. Kerner, The urge to the sea. The course of Russian history (Berkeley, 1942): 147-151, 165-175.

26. M. Sladkovskii, Istoriia torgovo-ekonomicheskikh otnoshenii narodov Rossii s Kitaem do 1917 g. (Moscow, 1974): 156, 161.

27. E. Besprozvannykh, Priamur'e v sisteme russo-kitaiskikh otnoshenii. XVII-seredina XIX veka (Moscow, 1983): 177. On the Chinese administration of the former Zunghar territories, see B. Gurevich, Mezhdunarodnye otnosheniia..., op. cit.: 167-175. 
In such conditions, it was all the more remarkable that Iakobi's son, Ivan (1726-1803), should have submitted a proposal to make war on China which shows great similarities with his father's recommendations during the turmoil of 17541757. Ivan graduated from the Corps of Cadets in 1747 and was sent to join his father in Selenginsk, where he spent fifteen years: obviously, he experienced the crisis at close hand. His father sent him to Peking as a courier on several occasions, giving him an excellent knowledge of the Mongol frontier. In 1769, he returned to Russia to fight in the Turkish war under Petr Rumiantsev - his father had fought under Rumiantsev's father - and was promoted to major general in 1774. Perhaps owing to Rumiantsev's recommendation, he became a protégé of Procurator General Alexander Viazemskii and the chief of the College of War, Grigorii Potemkin: he was appointed governor of Astrakhan in 1776, of Saratov in 1780, then governor general of Ufa and Simbirsk in 1782. A year later, he was back in Siberia as governor general of Irkutsk and Kolyvan. ${ }^{28}$ Like other governors of Siberia (Denis Chicherin and Evgenii Kashkin, for example) he lived in luxury and behaved like other great lords of Catherine's reign. ${ }^{29}$ This earned him many enemies, and he was recalled in 1788 following a denunciation that he had plotted war on China and shown disrespect toward the Senate. He was eventually cleared, and officially retired in 1797 with the rank of full general. ${ }^{30}$

\section{II}

Iakobi's proposal was undated, but was certainly written after his recall and before Catherine's death in $1796 .{ }^{31}$ It began with an explanatory statement. China's wealth had created a mood of "unbearable vanity" (prevoznoshenie). Its emperor,

28. RBS, 25 (1913): 56-57. See also D. N. Bantysh-Kamenskii, Slovar' dostopamiatnykh liudei russkoi zemli, 5 parts (Moscow, 1836), 5: 373-376.

29. V. Shtengel (Steinheil), "Sibirskie satrapy 1765-1819," Istoricheskii vestnik, 3 (July-Sept. 1884): 366-386. On Iakobi see 370-371.

30. He arrived in Petersburg in June 1788; neither the empress nor the favorite (Alexander Dmitriev-Mamonov) received him. Mikhail Garnovskii (who managed Grigorii Potemkin's glassworks in the capital) wrote that he in turn received only people who could help him; that, "he who greases the wheels moves faster, and the Irkutsk governor general has what he needs to grease them." See “Zapiski Mikhaila Garnovskogo 1786-1790," Russkaia starina, 2 (May-Aug. 1876): 1-32, here 17-18. The official decision to clear Iakobi is in Polnoe Sobranie Zakonov Rossiiskoi imperii (PSZ), 1st series, 1649-1830, 45 vol. (Petersburg, 1830), here vol. 23, 1793, N. 17166. It stated that he had received secret instructions with which the Senate was not familiar.

31. "Nachertanie $\mathrm{k}$ dvoistvennomu umnozheniiu polz, s rasshireniem predelov ot storony Kitaia," (hereafter "Nachertanie"), Chteniia, 4 (Oct.-Dec. 1858): 43-100. The proposal is undated. E. Besprozvanny, Priamur'e..., op. cit.: 194-195 claims that it was written after November 1796, i.e., after Catherine's death. This is impossible. The most convincing argument is that Iakobi also proposed an expedition against Persia, but made no reference to that led by Valerian Zubov in the summer of that year. Since Iakobi was in Petersburg or Moscow at the time, he could not possibly have ignored it. He also concluded by saying that he was moved by his "zeal and fidelity" to the monarch who once gave him his command in Irkutsk, something he would have been unlikely to say during Paul's reign. He referred in his 
protected by steppes difficult to cross for European troops, imagined that other peoples could not exist without his forbearance; its Tribunal - the Lifan Yüan responsible for China's relations with Mongols, Uighurs, Tibetans and Russians had been treating tributary peoples with contempt. ${ }^{32}$ These statements, were understandable when placed against the background of China's traditional assumption that its civilization was superior to that of the "barbarians" who sought access to it, but also in the context of the Ch'ien-lung emperor's reign of nearly 60 years, during which the Chinese empire reached unprecedented size and power. An expression of that celestial condescension was found in the edict restoring trade relations with Russia in 1792, where "the great and most holy sovereign who shows equal mercy to all human beings, accepted the respectful (blagosklonnoe) petition of the Russian Senate and consented to reopen the trade at Kiakhta" - a document which clearly looked on Russia as a subordinate and a vassal in the Sinocentric world order. ${ }^{33}$ The Russians, who yielded to no one in arrogance toward their own vassals in the Russo-Chinese frontier, could not accept such behavior. Iakobi was certain that the Manchu empire was "a colossus which can be crushed like porcelain." Therefore, the purpose of his proposal was "to humble the exorbitant pride" of China and force it to respect (earn a gromkoe uvazhenie) Russia's power and civilization - a purpose certain to appeal to the ruling elite of Catherine's reign obsessed with diplomatic successes and military victories.

Iakobi developed his argument in three parts: a description of the current boundary; the military operations; their aftermath, including a correction of the border, the expansion of trade, and new relationships with the Kazakhs and Mongols.

The boundary of his day began at Gurev on the Caspian coast, followed the Ural River to Ilets-gorodok (Sol-Iletsk) on the confluence of the Ilek, and continued along the Ural to Verkhne-Uralsk. The first segment was patrolled by the Ural and Orenburg Cossacks, secured the approaches to the left (lugovaia) bank of the Volga, and protected the mines of the southern Urals in Bashkiria against raids by the Kazakhs of the Small Horde. It was called the Orenburg Line, and was commanded by the governor general of Ufa and Simbirsk, Iakobi's former post.

introduction to his misfortune, i.e., his recall: therefore, the proposal must have been written between 1788 and 1793. The text also hints here and there that the proposal (or parts of it) was submitted to answer some specific questions: he may have been asked to present his views to answer the accusation that he had planned to embroil Russia in a war with China and explain a number of disputed issues. Even if the empress exonerated him, it is clear that he was a partisan of such a war which he considered necessary if not inevitable.

One may also speculate that his activities in Irkutsk (including the transfer of personnel) encountered the hostility of Prince Viazemskii who was still all-powerful in 1788 . He had a stroke in 1789 and remained incapacitated until his death in January 1793. To exonerate Iakobi in December would have made perfect sense.

32. On the Lifan Yüan, see M. Rossabi, China..., op. cit.: 160-161 and N. DiCosmo, "Qing colonial administration...," art. cit.: 294-295.

33. J. Fairbank, The Chinese world order. Traditional China's foreign relations (Cambridge, MA, 1968): 2-3, 20, 36-37. For the text of the edict see M. Sladkovskii, Istoriia..., op. cit.: 374-376. See also R. Quested, The expansion of Russia in East Asia 1857-1860 (Kuala Lumpur, 1968): 2-3. 
The boundary then crossed the steppe via Petropavlovsk to Omsk on the Irtysh, barring the Kazakhs of the Middle Horde from the Kurgan steppe all the way to the great bend of the Irtysh below Omsk, then followed the Irtysh past Semipalatinsk to Ust-Kamenogorsk, over 2,500 kilometers from Verkhne-Uralsk, keeping those Kazakhs from the pastures and the salt lakes of the Baraba and Kunlunda steppes. ${ }^{34}$ This second segment made up the Siberian Line whose commander reported to Iakobi as governor general of Irkutsk and Kolyvan. At Ust-Kamenogorsk began the so-called Kolyvan Line, built across the Altai Mountains to Kuznetsk to protect, against the Zunghars at an earlier date and now against the Chinese, the KolyvanVoskresensk gold mines and metallurgical plants of the Cabinet. This line was extended after 1763 from the mouth of the Bukhtarma to Lake Teletskoe, 600 kilometers from the Irtysh, bringing more of the Altai massif into the Russian empire and leaving the remainder, as well as the Lake Zaisan region, under Chinese jurisdiction. ${ }^{35}$ East of Kuznetsk to the Tunkinsk fort (ostrog) which guarded the approaches to Lake Baikal the border followed the impassable Saian chain, where the Russians kept no military presence. The fourth segment, 2,000 kilometers long, ran from Tunkinsk via Kiakhta, Kudara, and Aksa to Tsurukhaitui on the Argun River, the border with China, and followed it almost to its confluence with the Shilka, where the Amur began. It was sometimes called the Chinese Line. ${ }^{36}$

All these lines were not heavily defended - there were probably less than 20,000 poorly armed troops assigned to frontier defense over such enormous distances, and they could not have withstood a Chinese offensive - but they were largely sufficient to intercept Kazakh and Mongol raids and to draw a perimeter along which the world of the settler ended and that of the nomad began. Iakobi found this boundary unsatisfactory because it was unnecessarily long and crooked; it followed a huge arc of circle from the Caspian to the Altai, and then another from the Irtysh to Lake Baikal. He claimed there was an "old agreement" (postanovlenie) with the Zunghars according to which the entire course of the Siberian rivers flowing into the Arctic Ocean must be in Russia's possession, but that Russian claims had been held in abeyance ( $v$ molchanie do vremeni) because of "circumstances." ${ }^{37} \mathrm{He}$ obviously referred to Gagarin's claims, which, however, had not been recognized by the Zunghars, let alone the Kazakhs and the Chinese. The border also made too many zigzags east of Lake Baikal. Iakobi's intention was to straighten out the imperial boundary by incorporating part of the Kazakh steppe and Mongolia, as well as the valley of the Amur. Such a vast restructuring of the RussoChinese frontier could obviously not be carried out without first making war on China.

34. "Nachertanie": 47-50.

35. See the instruction to Lt.-Gen. Johann von Springer, Commander of the Siberian Corps (1762-1771), in PSZ, vol. 16, 1763, N. 11931.

36. "Nachertanie": 47-50, 99-100.

37. Ibid.: 49, 66 . 


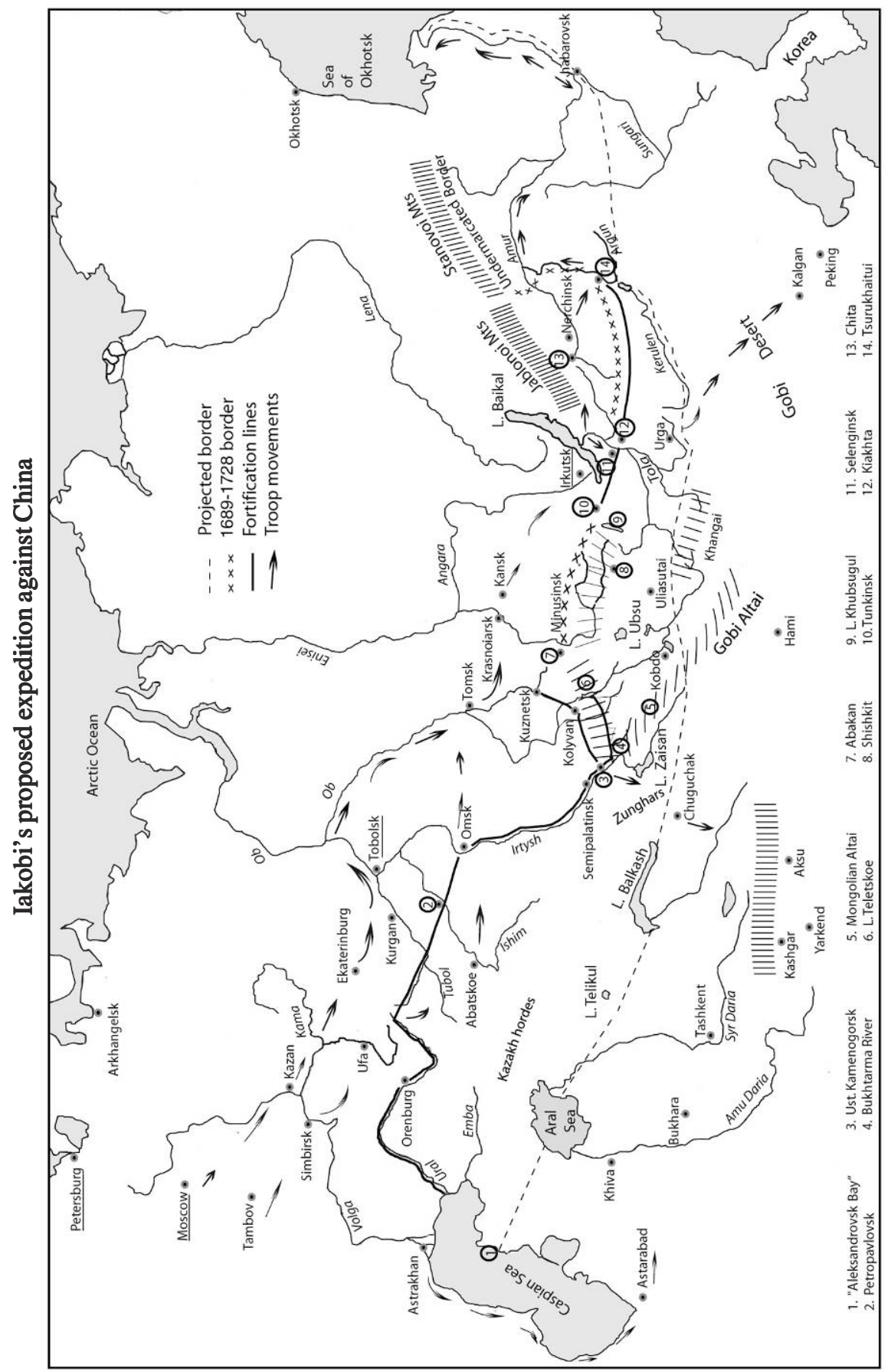


Such a war, he wrote, would require the creation of three corps: one consisting of 14,000 infantry and seven light cavalry regiments; a second of 6,000 infantry and three light cavalry regiments, ${ }^{38}$ both with enough siege and field artillery and pontoon bridges; and a third (or Kolyvan) corps of undisclosed strength but smaller. The bases of operations of the three corps would be Kiakhta, Nerchinsk, and Ust-Kamenogorsk respectively. To bring them up to full strength, troops would be brought from European Russia, some from the regiments stationed near Moscow. They would march via Vladimir and Kazan, cross the Urals at Ekaterinburg, sail down the tributaries of the Tobol to Tobolsk, down the Irtysh and up the $\mathrm{Ob}$ to Tomsk, and march on to Kansk on the postal road to Irkutsk. Other troops would set off from the Ukrainian provinces and march via Tambov and Simbirsk, Verkhne-Uralsk and Abatskoe on the Ishim to Kansk. From Kansk, the combined force would march on via Nizhne-Udinsk to Irkutsk, cross Lake Baikal and reach Verkhne-Udinsk (Ulan Ude), where the road divided: troops assigned to the first corps would march southward via Selenginsk to Kiakhta; those assigned to the second corps would march on to Chita, on the portage between the Khilok and the Ingoda on the Heartland's periphery, and to their final destination at Nerchinsk. The same two columns originating in European Russia would also detail some of their troops to make up the Kolyvan corps: from Ekaterinburg and Cheliabinsk these units would converge across the Kurgan steppe on Omsk, and from Omsk would follow the Irtysh to Ust-Kamenogorsk. Iakobi estimated it would take about a year for the troops to reach their destination and anticipated no difficulties: in March 1769, he had left Selenginsk at the head of his regiment and reached the theater of operations of the army facing Bendery in Bessarabia in February 1770 with a full complement and very few sick men. The artillery would leave Kazan in December in small detachments to insure an adequate supply of forage for the horses during the winter months. It would reach Tobolsk in the spring and Irkutsk in the fall, using the river network linking the Urals with Eastern Siberia. ${ }^{39}$

Such extensive troop movements in preparation for a war against a still powerful state, at great distances from the more densely settled regions of European Russia and in a sparsely populated and inhospitable frontier, raised difficult logistical problems: "there is no greater calamity for troops than to have to fight hunger in the midst of victories." 40 Iakobi planned to set up three magazines in Irkutsk,

38. According to the table of organization of April 1786, a "musketeer" regiment of two grenadier and 10 musketeer companies had a complement of 2,104 men, including 1,632 privates. Iakobi thus had 10 infantry regiments for the first two corps. A "light cavalry" regiment of six squadrons had a complement of 1,128 men including 828 privates. The first corps would thus consist of about 16,000 men, the second of about 9,500: see PSZ, vol. 43, part. 1. 1786, N. 16376: 212-218 and 1795, N. 17639: 259-267.

39. The distance from Moscow to Kiakhta on the Mongolian border via Ekaterinburg (Sverdlovsk), Omsk, Krasnoiarsk, Irkutsk and Verkhne-Udinsk is 6,029 kilometers; from Verkhne-Udinsk to the Mongolian border on the Argun, 1,145 kilometers; from Omsk to Ust-Kamenogorsk, 1,003 kilometers.

40. "Nachertanie": 53-63. 
Selenginsk and Kiakhta for the first corps of 21,000 men, ${ }^{41}$ the largest of them in Irkutsk. He estimated it could be filled with local grain. There was some wishful thinking here, not unusual among Russian military commanders, because the agricultural base of Eastern Siberia was both small and vulnerable to weather changes and speculative buying by Chinese merchants. ${ }^{42} \mathrm{He}$ did not think it was possible - obviously answering here a query from some anonymous reader of his original text - to buy grain from Krasnoiarsk and Achinsk in the valley of the Chulym and have it shipped down the Enisei and up the Angara to Irkutsk because it would cost too much: navigation on the Angara was obstructed by rapids and slowed by the river's swift current on the upstream run.

So the Irkutsk store would have to be filled up with local grain, and it would feed the other stores. Troops would cross Lake Baikal between the beginning of March and April 10, when the ice usually broke up on the lake. Shallow-draft boats would then transport the provisions to Kiakhta by way of the Selenga; and the Kiakhta store would in turn supply the troops advancing into Mongolia toward Urga (Ulan Bator). The main store for the second corps of 9,000 men stationed in Nerchinsk would be in Chita. It could not be filled with local grain and would have to depend on purchases in Verkhne-Udinsk district, where settlements on relatively good land along the Chikoi River promised to yield an adequate supply. From VerkhneUdinsk the grain would have to be transported across 500 kilometers of steppe to Chita on ox-drawn carts and by water from Chita to Nerchinsk on the Ingoda and the Shilka. From Kiakhta and Nerchinsk, the troops would go on the offensive with a four-month supply of biscuit (sukhari). Provisioning the third corps presented no difficulties: the Altai region had enough settlers and land: the main store in UstKamenogorsk could easily supply the troops advancing toward Lake Zaisan. ${ }^{43}$

The operations were planned for the spring. The mission of the Kolyvan corps was simple: to take possession of Lake Zaisan, move on to Chuguchak (Tarbagatai) and occupy the Chinese towns on the Ili River, across the great gap between the Mongolian Altai and the Tien Shan Mountains. The advance would cut off the pastures of the Large Kazakh Horde from Chinese Turkestan and pave the way for the horde's integration into the Russian empire. Its mission accomplished, this corps would then open a third front to draw the Manchus-Chinese into Western Mongolia. In the meantime, the first and main corps would cross into central Mongolia from Kiakhta and march on to Urga, 400 kilometers away. To protect their rear against a possible Chinese counterattack in the basin of the Selenga, Iakobi recommended raising the number of border troops to 10,000 men and to draft some 40,000 Buriats to form a Cossack-like "host" modelled after the Don Cossacks. The Gobi steppe began at Urga, and it was another 900 kilometers to

41. It is not clear how Iakobi reached this figure of 21,000 men, even after including the artillery units and the sappers.

42. For an example of such speculative buying see Governor General Ivan Pestel's report to Police Minister Alexander Balashev of January 1812 in Vneshniaia politika Rossii, 6 (1962): 261-262.

43. "Nachertanie": 53-63. 
Kalgan (Zhangjiakou) on the Great Wall of China, along a caravan trail without any vegetation except wormwood and without water except from wells - the corps would have to keep a pioneer unit to open up and scour the wells ahead of the troops and their horses. ${ }^{44}$ From Kalgan, it was another 340 kilometers to Peking. Iakobi, who had travelled the route several times when his father sent him as a courier to the Chinese capital, estimated that Chinese fortresses were poorly built and defended, and expected no resistance. The Chinese infantry had obsolete equipment and hardly any artillery; the cavalry consisted of Mongols armed with bows and arrows. Moreover, relations between the Manchus-Chinese and the Mongols were unfriendly, and Iakobi sensed that the latter would switch over to the Russians in the event of a Russian victory. ${ }^{45}$

The mission of the second corps was extremely ambitious. From Nerchinsk, it would move to the Argun, cross the river at Tsurukhaitui, take Khailar in Eastern Mongolia, follow the Argun to where it merges with the Shilka to form the Amur. At the confluence of the two rivers, it would build a fortified outpost and a magazine, then sail down the Amur, occupying villages on the right bank and building more forts every 150 to 250 kilometers. The artillery would follow on boats: Iakobi wanted 300 guns, 100 of which were already in Irkutsk, while the others would come from Russia and the ironworks of Krasnoiarsk and Irkutsk: they were in poor working condition but could be restored. Some 300 boats were considered necessary to transport provisions as the expedition kept advancing toward the mouth of the river. Once it was reached, the boats, the artillery, and the forts would become the logistical infrastructure for the establishment of Russian military rule on the Amur. The occupation of its valley, from which the Russians had been kept since 1689 - would force the Manchus-Chinese to renegotiate the treaties of Nerchinsk and Kiakhta and cede both banks to the Russian empire. They would have lost their Mongol cavalry, their elite force. If they refused to renegotiate the treaties, the first corps in Urga would swing into action, cross the Gobi desert on the way to Peking to deal "a blow that would shake (the Manchu state) to its foundations."46

44. F. Grenard, Haute Asie (Paris, 1929): 251-258, 264-265, and Th. Barfield, The perilous frontier..., op. cit.: 16-18.

45. "Nachertanie": 53-54.

46. Ibid: $57-58$. It is interesting to compare Iakobi's proposal with another recommendation to make war on China by Gerhard Friedrich Müller (Miller, 1705-1784), one of those foreigners in Russian service who identified with the empire and volunteered considerations and memoranda on how it must expand to realize its potential and achieve eventual hegemony within the Heartland. Müller was a major figure among the eighteenth-century "Russian" geographers and historians. He spent ten years in Siberia from 1733 to 1743, collected an enormous amount of documents from the Siberian archives and wrote the first history of Siberia: it ends in 1661. On him, see P. Pekarskii, Istoriia Imperatorskoi Akademii Nauk v Peterburge, 2 vol. (Petersburg, 1870-1873), 1: 308-430. See also A. Pynin, "Russkaia nauka i natsional'nyi vopros v XVIII-m veke," Vestnik Evropy (May-June 1884): 147-149, 581-585 and, more recently, J. Black, "G.F. Müller and the popularization of Siberian history, geography, an ethnography in the eighteenth century," in B. Chichlo, éd., Sibérie II. Questions sibériennes (Paris, 1999): 197-209. His recommendation was published in N. Bantysh-Kamenskii, 
While it thus appears that the chief purpose was to gain for Russia the valley of the Amur, the expedition also had other far-reaching objectives. One was a substantial rectification of the Mongolian border. Iakobi wanted Urga to become Russia's new military headquarters in the region, extending the imperial boundary 400 kilometers south of Kiakhta, and the Gobi desert to become the new border between the Russian and the Chinese empires. ${ }^{47}$ East of Urga, the new border followed the Kerulen to Lake Dalai, continued along other rivers of northern Manchuria to the lower "Usuliagin" and followed it to its confluence with the Amur. Iakobi, insisted that the entire valley of the Amur must pass into Russian possession - instead of drawing the border along the river's thalweg as was the usual practice. At the mouth of the Amur, a new port would establish trade relations with Canton, vastly expanding Russia's commercial possibilities which had been so constricted by the prohibition to trade anywhere but at Kiakhta. ${ }^{48}$

Diplomaticheskoe sobranie..., op. cit.: 378-393. It is dated 1763. On the proposal, see L. Maier, "Gerhard Friedrich Müller's memoranda on Russian relations with China and the reconquest of the Amur," Slavic and East European Review, 59 (1981): 219-240. I will cite this document as Müller. Müller envisaged three subsequent campaigns against China, from the upper Irtysh and Krasnoiarsk, from Selenginsk and Nerchinsk; only the operations from the last two towns would be offensive. Each corps would consist of ten infantry and two Cossack regiments and Buriat irregulars, a larger force than Iakobi's. The expedition from Selenginsk would expel the Chinese from Mongolia, that from Nerchinsk from the Amur valley. Ten magazines with a three-year supply of provisions would be built across Siberia. Müller thought it would be useless to try to invade China: the Gobi Desert was not worth the cost of conquest, it should become instead the new frontier between the Russian and Chinese empires. He also had no doubts about a Russian victory: one Russian soldier was worth ten Chinese, Müller: 386-388.

47. Uliasutai was the headquarters of the Manchu administration of both Western and Eastern Mongolia until 1786, when Urga was given independent status and became the center of Manchu administration in Eastern Mongolia. It was also the residence of the khutukhtu: R. Rupen, "The city of Urga in the Manchu period," Studia Altaica, 5 (1957): 157-169, here 159.

48. "Nachertanie": 72-73. The Kerulen flows into Lake Dalai, a salt lake which used to be connected by a canal at high water with the Argun and was sometimes considered a tributary of the Argun-Amur: see L. Gibert, Dictionnaire historique et géographique de la Mandchourie (Hongkong, 1934): 435-436. The connection no longer exists, although Rerikh could still write in the twentieth century that the Kerulen belonged to the basin of the Pacific Ocean, Iu. Rerikh (G. Roerich), Tibet..., op. cit.: 290-291. See also T. Holdich, Political frontiers and boundary making (London, 1916), calling the lake "an incident" in the course of the Kerulen-Argun. A century earlier, Timkovskii took note of the already existing controversy and was convinced, in accordance with Chinese sources, that the Argun came out of Lake Dalai: G. Timkovski, Travels of the Russian mission through Mongolia to China, and residence in Peking, in the years 1820-1821, 2 vol., 1 (London, 1827): 152-153.

The Uliasugin remains a mystery. The context shows that it was a rightbank tributary of the Amur, but such tributaries are few and insignificant. I assume it was the Sungari, whose lower course would be aligned with the "straight" boundary Iakobi was looking for between Urga and the Amur: L. Gibert, Dictionnaire..., op. cit.: 820-823. A map of 1787 in my possession lists the Sungari as the Sougali Ula.

Müller postulated that the end purpose of the expedition from Selenginsk was to build a fortified line similar to those built over the years across the northern Ukraine, in the Orenburg Territory and in Siberia, with a new military headquarters on the Tola River. It is unclear how he would draw the border to the east, to the Amur: probably along the Kerulen and the Sungari, as Iakobi planned, Müller: 388-391. Together with the annexation of "the best land in all Mongolia," the establishment of such a military headquarters would enable the Russians "to dictate the laws" to Manchu China, Müller: 387. 
To the west, the new border followed a nearly straight line to the headwaters of the Irtysh, bringing into the empire the entire basin of the Selenga and skirting the Gobi desert to the source of the Irtysh. From there, it ran along the Tarbagatai chain to Lake Balkhash, bringing Lake Zaisan into the empire. From Lake Balkhash it continued to Lake Telikul and the Syr Daria to the Aral Sea and beyond that sea to "Alexandrovsk Bay" on the Caspian. ${ }^{49}$ Despite this apparent clarity, however, Iakobi's text is in fact hopelessly confused, most likely because of inadequate knowledge of the region's geography, as he himself conceded. He answered the question whether the new border would go through Kobdo by saying that it would run from Urga to the source of the Shishkit (to the west of Lake Khubsugul (Kosogol, Hövsgöl)), which then becomes the Little Enisei; follow the foothills of the Altai massif to the source of the "upper Irtysh;" turn right along Lake Zaisan and run on to Lake Balkhash, via the Emel River. Such a border happened to be very close to that between Mongolia and the former Soviet Union after 1944, but it did not place the Kobdo depression within the empire. It is not clear how one could draw a "straight" line from Urga to Lake Balkhash without including Kobdo, while such a line could easily have followed the postal road from Urga to the Manchu headquarters at Uliasutai and Kobdo, crossed the Mongolian Altai to reach the source of the "upper" or Black Irtysh. Iakobi's avoiding to answer the question about Kobdo showed well that "it unfortunately happens that the necessity (to have a well-marked boundary) is often in advance of accurate geographical knowledge" and that "nothing but the necessity imposed by ignorance can impose the adoption of the straight line." 50

Müller was saying very much the same thing as Iakobi: Urga is on the Tola River (Tuul Goll) which flows from the east into the Orkhon, a tributary of the Selenga. Its headwaters flow parallel to those of the Kerulen. The river also ran along an ecological boundary, the territory north of it being indistinguishable from southern Siberia and the land of the Buriat Mongols. Timkovski wrote that "in the track of country from Kiakhta to Urga, we might still fancy ourselves to be travelling in the Russian frontier provinces, inhabited by the Buriats, the scenery and the productions are so similar; but at the very first stop beyond the Tola, we perceived we were in a different country; ... we entered the dreary and melancholy deserts of Mongolia," G. Timkovski, Travels ..., op. cit., 1: 140; on the Tola and its valley, see 2: 236-237 and 428 .

49. Lake Telikul, like Dalai, was a lake fed by a landlocked river, here the Sary-Su, see John and Robert Michell (eds), The Russians in Central Asia, op. cit.: 16. My 1787 map places Alexandrovsk Bay south of present-day Fort Shevchenko, behind Cape Peschannyi.

50. T. Holdich, Political frontiers ..., op. cit.: 169. Iakobi's confusion may have been due to the fact that some Russian maps $(1706,1776)$ showed the Selenga not descending from the Khangai upland but issuing from Lake Hubsugul. The new boundary would thus follow the river to the lake and then cross over to the Little Enisei: G. Cahen, Les cartes..., op. cit.: 147 , 186, 330-331. The area was not well explored until the beginning of the twentieth century, see V. Sapozhnikov, Mongol'skii Altai v istokakh Irtysha i Kobdo (Tomsk, 1911): 188-197.

Müller was more specific about the Mongolian segment of the new border. After the Chinese destroyed the Zunghars, the (unofficial) Russo-Chinese border in the west ran along the Bukhtarma, a tributary of the Irtysh descending from the Altai. Müller felt that Russia's military success in the proposed campaign would justify advancing the border to include Lake Zaisan and the "upper Irtysh," undefined both by him and by Iakobi. It would then run along the crest of the Altai to Lake Ubsu (Uvs Nuur), the Tes River which flows into it from the east, to Lake 
Be it as it may, Iakobi believed that the new straight border from Lake Zaisan to the mouth of the Emba (which happened to be much to the north of Alexandrovsk Bay) would reduce the empire's defensive perimeter by 2,500 kilometers, from 3,714 to 1,200 kilometers. ${ }^{51}$ And beyond Urga, there would also be straight line to the lower course of the Sungari west of Khabarovsk. Such a border would be much easier to defend with forts built anywhere between 50 and 200 kilometers and redoubts every 25 kilometers, from which patrols would keep a constant watch over the Manchus-Chinese. Iakobi estimated that the distance from Ust-Kamenogorsk to Urga was about 1,500 kilometers, which mounted troops could cover in 15-16 days at the rate of 70-80 kilometers a day, ${ }^{52}$ while the contemporary defensive perimeter from Ust-Kamenogorsk to Kiakhta via Tomsk, Krasnoiarsk and Tunkinsk was 2,480 , or 1,000 kilometers longer. The total length of the border from the Caspian to Urga would thus be reduced by some 3,500 kilometers. Beyong Urga, Iakobi was hesitant to give an estimate "because many of the places are unknown." Even if we overlook his ignorance of certain geographical details, it is quite obvious that his overall perception of Siberia and of Russia's security needs in it were identical with those of Gagarin and the College of Foreign Affairs three generations earlier: Siberia was the basin of the Arctic Ocean, and it included Northern Mongolia. His new boundary from Urga to the Caspian via Lake Balkhash and the Aral Sea ran roughly along the watershed separating that basin from the Aralo-Caspian depression. His proposal merely sought to carry out in the field assumptions which had been the foundation of Russia's imperial policy in the region for a long time.

More was involved than security considerations. The advance of the boundary would open up the Kazakh steppe to settlement, and there was already some land fever among the Cossack population along the old but artificial boundary between the Ural and the Irtysh. The colonization of the steppe would at least guarantee an adequate food supply for Western Siberia. The flatlands and meadows of Northern Mongolia also offered attractive possibilities to the still few settlers of Eastern Siberia confined by the Saian and Iablonoi massifs to patches of steppe scattered over an enormous territory and buried under deep snows for several months. Even more attractive were the possibilities east of Urga. The new boundary would incorporate the fertile lands of Northern Manchuria and give the Russians access to the rich central plain: Russian settlements in Eastern Siberia would no longer have

Sangin (Sangiyn Dalay Nuur), placing the headwaters of the Enisei in the Russian empire, and on to the Selenga, where the Russians would build another military headquarters connected with Irkutsk by a road to be built across the mountains and to run along Lake Hubsugul. It seems that both Müller and Iakobi would leave the Kobdo depression in the Chinese empire while annexing the left bank of the Amur. For the basin of the Tes, Lake Sangin and the upper Enisei, see Grum-Grzhimailo, Zapadnaia Mongoliia..., op. cit., 1: 155-157, 197-254.

51. "Nachertanie": 63-71, 73-76, pt. 4-5.

52. Ibid.: 73. In January 1796, the Commander of the Siberian Line, Lt.-Gen. Gustav Strandmann, reported to the College of Foreign Affairs that Kobdo was about 12 days' journey from the Bukhtarma and Peking an 18-days' journey from Kobdo. At a rate of 50 kilometers a day, it would take 30 days to travel the 1,500 kilometers to Peking, Mezhdunarodnye otnosheniia..., op. cit., 2: 211-213. 
to suffer hunger. Such a vision of a Russian empire in the east, where settlers would have enough to eat to support themselves and maintain an adequate logistical infrastructure for the imperial army, would remain an integral feature of Russia's Siberian policy: in 1916, nearly 125 years after Iakobi submitted his proposal, the Governor General of Turkestan (and former war minister and commander in chief of the Russian army during the Russo-Japanese war), Alexei Kuropatkin, recommended to Nicholas II that the border with Mongolia and Manchuria be shortened by 4,000 kilometers by advancing it to form a nearly straight line running from the Khan Tengri peak of the Tien Shan to Vladivostok, incorporating Zungharia, Northern Mongolia and Northern Manchuria into the Russian empire.53

\section{III}

Iakobi's proposal raised many questions. Even if it is possible that the ManchuChinese war machine was no longer as efficient by the end of the eighteenth century as it had been at the time of the great onslaught of the 1750 s, when some 150,000 troops were sent over 4,000 kilometers to fight the Zunghars, the 25,000 to 30,000 men assigned by Iakobi to his expedition seem like a paltry force to engage against the Manchu "bannermen," Mongol cavalry and Chinese foot soldiers, many of them stationed around the capital. Russia's military potential in Siberia was insignificant, while the Manchus could count on an inexhaustible reserve of manpower. ${ }^{54}$ A comparison with the opening of China by the British in 1842 is not apposite: the capital was better defended than Canton, and crossing Mongolia exposed the Russians to counterstrikes from Manchu forces in Mongolia and Manchuria and to the danger of being cut off from their bases. Any attempt to change the status quo in these two territories was certain to be seen as a threat to Manchu China's vital interests: central Manchuria was the homeland of the dynasty, from which the Chinese were kept out until the very beginning of the twentieth century, and the long struggle with the Zunghars had shown how sensitive Peking had been to Mongol unrest. Iakobi's proposal had its place in traditional Russian strategy of launching deep strikes into enemy country aiming at the capture of the capital, but such a small force, and one that would inevitably become depleted by the necessity to garrison watering places and convoy supplies

53. A. Lobanov-Rostovskii, Russia and Asia (Ann Arbor, 1951): 256. The editor of N. N. Bantysh-Kamenskii's Diplomaticheskoe sobranie (originally published in 1803) made a remarkably similar statement in 1882, see his end article entitled "Soobrazheniia po voprosu o sushchestvuiushchikh granitsakh Rossii s Kitaem": 535-544, esp. 542-544. For later ambitions in the Far East, including the views of Kuropatkin, Nikolai Przhevalskii in the 1870s, and the ambitions of Peter Badmaev in the 1890 s, see D. Schimmelpenninck van der Oye, Toward the rising sun. Russian ideologies of empire and the path to war with Japan (Dekalb, IL, 2001): notably 27-41, 99-103, 197-200. See also P. Tang, Russian and Soviet policy in Manchuria and Outer Mongolia 1911-1931 (Durham, NC, 1959).

54. On the one occasion when the Russians and the Chinese almost went to war, the Chinese taking a strong stance in the 1870 s, the Russians backed down, I. Hsü, The Ili crisis. A study of Sino-Russian diplomacy 1871-1881 (Oxford, 1965): 38-39, 47-52, 94-100. 
across the 1,500 kilometers of Mongol territory, had no chance of taking the Chinese capital and shaking the Manchu empire to its foundation. ${ }^{55}$ Moreover, at a time when Russia was about to enter the long conflict with Revolutionary France for hegemony in Central Europe, it could not afford to take the risk of a defeat in China or to transfer substantial forces to the Eastern theater for a protracted effort which the limited resources of Siberia in manpower, manufactures and provisioning made it impossible to sustain. ${ }^{56}$

The assumption that the Mongols would side with Russia was not borne out in 1757, and the chances were even less at the end of the century. After crushing the Zunghars, Peking had consolidated its imperial infrastructure in Mongolia with the appointment of a viceroy (amban) in Urga who dealt with Russo-Chinese relations, while the military governor of Uliasutai kept a strong military presence in Western Mongolia. The integration of the Mongol nobility into the imperial elite by marriages and the grant of privileges, and of the Mongol market into the imperial economy with the help of well financed Chinese merchants who fanned out from Urga to sell their wares in the countryside, drew Mongolia irresistibly toward China rather than Siberia and generated a vested interest in maintaining the status quo supporting Manchu rule. Nevertheless, Iakobi had to face the implications of his proposal to move Russia's military headquarters to Urga and bring the Khalkhas into the empire. There would be too many Mongols along the new border, it was claimed, and the Manchu authorities would continue to use their network of spies and clients to destabilize it and restore their influence among the clans whose allegiance was always fickle. To counter this danger, Iakobi proposed to resettle some of the Khalkhas deeper into Siberia to pastures between Krasnoiarsk on the Enisei and the Kan River (a tributary of that river) on the northern approaches to the Saian, and to the Koibal steppe south of Abakan, surrounded by nearly impassable mountains. Those remaining in Mongolia would be trained to form a kind of Cossack force to patrol the new border with China.57 Iakobi even hoped that the Kalmyks who had fled Russia in 1771 and had been resettled by the Manchus in the Ili region could be brought back to the trans-Volga steppe and coralled (zamknuty) between the Trans-Kama and Ural fortified lines, where they would become harmless and contribute to the settlement of a largely empty territory. There was great similarity between these views and those of Iakobi's father and Governor Miatlev in the 1750s. The deportation of the Mongols from their homeland would help the settlement of the inner frontier of the Russian empire and create a kind of no man's land between the Russian and Chinese empire, not unlike the Manchu

55. See my book, The grand strategy of the Russian empire, 1650-1831 (New York: Oxford University Press, 2003). Two excellent descriptions of the Kiakhta-Peking caravan road are in N. Bichurin (Iakinf), Zapiski o Mongolii (Petersburg, 1828): 33-125 and G. Timkovski, Travels...,op. cit.: 10-319.

56. This was certainly the opinion of Müller who, although not a military man, sound at times more realistic than Iakobi, Müller: 390 .

57. "Nachertanie": 68-69. 
policy of keeping Northern Manchuria void of inhabitants in order to minimize disputes between the two empires.

The new boundary would also bring the area of Lake Zaisan and the entire Kazakh steppe into the empire. By the time Iakobi submitted his proposal, the Kazakhs' traditional political world was disintegrating. The khans of the Small Horde owed their selection and confirmation to the imperial authorities in Orenburg; the northern clans of the Middle Horde were turning to Russia, while the others looked to China; and the Large Horde, which roamed between Lake Zaisan and Lake Balkhash, remained a vassal of the Manchu empire. Iakobi's new border would bring it into the Russian empire and roll back the Manchus behind the Zungharian Gate. There could be no question of deporting the Kazakhs, but they would have to "get used to obey." Beyond the Kazakh steppe lay the Aralo-Caspian depression and Central Asia, with Tashkent, Bukhara and Khiva, its major commercial cities. They linked Siberia with the trade routes from China, Persia and the Ottoman empire, but these trade routes were also threatened by the constant depredations of the Kazakhs, who robbed the caravans travelling across the steppe to and from Orenburg, Petropavlovsk and Semipalatinsk. The inclusion of the steppe within the imperial perimeter and the stationing of garrisons at strategic locations would restrain the Kazakhs by the threat of retaliation and eventually allow the empire to draw tax revenues from the nomads. ${ }^{58}$ When we consider that Iakobi also contemplated a military invasion of Persia, coordinated with his Mongolian campaign, which would take Russian troops along the entire southern shore of the Caspian to Astarabad (Gorgan), from where they could strike at Bukhara, it becomes obvious that he was thinking in terms of a huge pincer movement directed against Central Asia, ${ }^{59}$ which built upon Peter I's expeditions against Khiva and northern Persia and anticipated the campaigns of the 1860s and 1870s, which brought Central Asia into the Russian empire.

Central Asia was not the only territory where Iakobi had commercial ambitions. The importance of trade in the study of Russian foreign and military policy is sometimes downgraded in favor of strategic factors; in fact, strategic and commercial ambitions could not be separated. The Russian advance into the great sea basins - the Baltic, the Black Sea, the Caspian, and the Pacific - was fueled by commercial ambitions: to tap the revenues of international trade for largely fiscal purposes, i.e., to raise the revenues of the Romanov house and the ruling elite. From Irkutsk, the road to riches led not only via Urga to the markets of Northern China, but via the Amur to Japan, Korea and the Pacific. Russo-Chinese relations in the eighteenth century were dominated by trade issues, and it was the Russians who kept pushing the Chinese to maintain the flow of trade and to reopen the Kiakhta mart whenever the Chinese closed it for essentially political reasons. The Kiakhta trade was for the Chinese a form of managed or "administrative trade," expressing a contractual rather than an economic relationship and resembling tribute, in which

58. Ibid.: 47-53.

59. Ibid.: 89-96, 99. 
the "barbarians" brought the products of their lands as an offering to the emperor of a Sinocentric universe which was conterminous with the entire known world ${ }^{60}$ Valuable sables and other furs, which cost nothing to prepare because they were collected from the natives in lieu of taxes, were exchanged in Peking for gold, silver, and precious cloth with which local officials, left to "feed themselves" as best they could by a government that looked on Siberia as an object of plunder, could amass a substantial fortune. Iakobi's father, for one, died a rich man. ${ }^{61}$

The Treaty of Kiakhta (1727) had sought to regulate the Sino-Russian trade by removing Russian traders from Peking, Northern China, and Mongolia, and confining them to Kiakhta on the new Mongolian border, much in the same way as trade with the "Western barbarians" coming from beyond the seas was restricted to Canton. ${ }^{62}$ The treaty was thus both a commercial and a boundary agreement tracing a linear border demarcating the Russian empire from China's client state in Mongolia, but one which destroyed the natural geographical unity of the basin of Lake Baikal. Iakobi's ambition to advance the border to Urga must thus be seen as an attempt to abrogate the treaty and return to an earlier situation in which the Russians could hope to draw the entire basin of the Selenga - the land of the Khalkhas - into the commercial orbit of Irkutsk and Lake Baikal. The attempt failed but, following the collapse of the Manchu dynasty in 1911, it was renewed and had become largely successful by $1917 .{ }^{63}$ The treaty also limited the official trade to one caravan to Peking every three years, but only six were sent between 1727 and 1754, and the caravan trade was then abandoned. The Russians continued to trade (illegally) in Mongolia, importing chiefly tea, tobacco and horses. The private trade in Kiakhta remained active because it was valuable to both sides, Chinese claims to the contrary notwithstanding. With the gradual depletion of the stock of sables, the Chinese gave pride of place to the red fox and the Kamchatka beaver, and the Russians imported gold and silver, in which the empire was still deficient: China had a large supply because it demanded a tribute in gold from its tributary states. The Russians also imported precious stones and silk. Tea became an increasingly important item: the Russians consumed black tea and resold green tea to the Kalmyks and Kazakhs. The so-called "kitaika" was the major textile export. The Kiakhta trade amounted to 60 percent of all Russian exchanges with "Asia." It attracted the entire foreign trade of Siberia, Kamchatka, the Aleutian Islands and Alaska, even Prussian textiles, from the other end of the Heartland. And

60. J. Fairbank, The United States and China, 4th ed. (Cambridge MA, 1979): 158-160 and J. Fairbank, The Chinese world order..., op. cit.: 63-65, 75-82.

61. At the time of his death, Ivan Iakobi had 6,000 serfs and his father had transferred a large sum of money to England: D. Bantysh-Kamenskii, Slovar' ..., op. cit.: 376.

62. A. Galperin, "Russko-kitaiskaia torgovlia s XVIII-pervoi poloviny XIX veka," Problemy vostokovedeniia, 5 (1959): 217-227. In 1805, a Russian squadron sailed around the globe and cast anchor at Canton hoping to establish a precedent, but the Chinese refused an offer to trade, E. Besprozvanny, Priamur'e..., op. cit.: 209-212.

63. P. Tang, Russian and Soviet policy..., op. cit.: 341-358. 
it encouraged the construction of a new Siberian trail bypassing Tobolsk, running from Ekaterinburg via Tiumen, Tomsk and Krasnoiarsk, and on to Kiakhta. ${ }^{64}$

But it was a market with little potential for growth, not only because the Chinese kept it tightly controlled, but also because the logistical difficulties in bringing the furs from the Aleutians and Alaska to Kiakhta were stupendous. The time was not far away when American and British ships would bring their cargo to Canton, confirm the superiority of sea-borne trade, and destroy the Kiakhta trade. The only solution was to gain access to the Pacific coast, build a port at a location more favorable than Okhotsk, and ship the furs to Canton - providing one overlooked the fact that the Chinese considered the Russians to be "barbarians" from the Heartland's interior, who could trade only at Kiakhta. At any rate, a sea-borne trade in furs would help open up relations with Japan and Korea, although the market for furs would inevitable shrink as it moved southward toward the warmer regions. Such concerns explain the Russians' recurring interest in the Amur: it was the only major river of Siberia that flowed eastward toward the Pacific: the Pacific basin was another large one where the Russians must make their presence felt.

The commercial concerns of Siberian officials went beyond the necessity to develop the market for furs: much larger considerations were involved. Eastern Siberia was in the permafrost zone, hardly hospitable to human settlement, let alone agriculture. The census of 1795 gave for the immense province of Irkutsk a taxable population of under 200,000 males. ${ }^{65}$ Isolated pockets of steppe and black soils were not sufficient to produce enough food even for the existing population. Famines occurred repeatedly, and even the garrisons suffered hunger. The uniformly mountainous terrain created ever-present obstacles for the transportation of supplies to isolated settlements. Beginning in the eighteenth century, there were concerns about Russia's staying power in Eastern Siberia and the coastal zone beyond the Heartland's periphery, for even that coastal zone suffered from such unforgiving climate that it could attract no permanent settlement of any importance. Okhotsk was icebound beginning in October and had no hinterland; nor did Petropavlovsk, which had to be supplied by sea. If Eastern Siberia was to become the foundation of a Russian empire in the Northern Pacific, its population had to grow large enough to provide adequate manpower and tax revenue, and its manufactures had to develop to the point where they could produce military and naval equipment. This manufacturing activity was in turn inseparable from the expansion of the region's foreign trade. Food supplies would have to come from beyond the sea, from Japan and Korea for example, and even as far away as the Philippines, where rice was grown in abundance. Only thus could Russia overcome

64. M. Sladkovskii, Istoriia..., op . cit.: 162-163, 167-169, 172-174. "Kitaika" was a light cloth, usually blue or black, sometimes cherry. On the Kiakhta trade, see A. Radishchev, "Pis'mo o Kitaiskom torgovle," in Polnoe sobranie sochinenii, 3 vol. (Moscow, 1938-1952), here 2 (1941): 5-35.

65. V. Kabuzan, Izmeneniia v razmeshchenii naseleniia Rossii v XVIII-pervoi polovine XIX $v$. (Moscow, 1971): 111. See also Opisanie Irkutskogo namestnichestva 1792 goda (Novosibirsk, 1988): 49; of these 186,096 males only 57,633 were (presumably) Russian peasants. 
the limitations imposed by the Chinese on commercial exchanges at Kiakhta. For Iakobi, the Asian coastland must become the vibrant periphery of the eastern end of the Heartland and Eastern Siberia the commercial hub of a vast economic region, in which Russia would export furs and manufactured goods in exchange for gold, silver and food products. Similar considerations would continue to inform Russia's Far Eastern policy under Governor General Nikolai Muravev (1847-1861) and Finance Minister Sergei Witte (1892-1903) for whom, as for a long line of Russian rulers and statesmen from Ivan IV on, Russia must become the intermediary between the trade of the East and that of the West.

The exploration of the Kuril archipelago led to Japan or, more precisely, to the island of Hokkaido. The same pursuit of fur-bearing animals which had taken the trappers to the Aleutian Islands sent them to the Kurils, and the entire archipelago had been explored by 1770.66 In the process, the Russians had come into contact with the Japanese: shipwrecks had left Japanese fishermen stranded as far north as the Kamchatka coast. Some were even taken to Petersburg, others were used to teach Japanese in Irkutsk, but they contributed little to a knowledge of the political conditions and economic situation in Japan. Iakobi was not sure whether Hokkaido was one or two islands or even part of the continent. There was a Japanese governor, but the local people were rebellious. Of interest, however, was the fact that they traded with Korea in various kinds of foodstuffs: Hokkaido was an attractive agricultural prospect. Iakobi knew that the country was closed to Christian shipping with the exception of the Dutch who traded on an island in Nagasaki Bay, but perhaps the Dutch could be induced to trade with the new port which the Russians would build at the mouth of the Amur, once they had forced the Chinese to surrender their control of the river. He had heard that the country was rich in gold and silver and appreciated that Japanese porcelain and lacquered dishes were superior to those made in China. The Russians were already familiar with Japanese tools, although Iakobi does not mention them. ${ }^{67}$

But the governor general let his fragmented knowledge get the better of his judgment: all attempts to reach Japan and induce its government to open up the country were fated to fail. In 1775, the governor of Irkutsk had organized an expedition to visit Hokkaido, but it was shipwrecked. In 1781, two merchants, Grigorii Shelikhov and Ivan Golikov, had founded a company to finance expeditions to China, Korea, Japan, India, and the Philippines to find additional markets for furs and fish and to obtain rice and salt, of which there was a severe shortage in Eastern Siberia. The company's activities never extended far beyond the Aleutian Islands and Alaska. ${ }^{68}$ More disappointing news came in with the

66. J. Stephan, The Kuril Islands. Russo-Japanese frontier in the Pacific (Oxford, 1974): 49, 61-68.

67. "Nachertanie": 78-80.

68. E. Fainberg, Russko-iaponskie otnosheniia v 1697-1875 gg. (Moscow, 1960): 47-48, 50-51; E. Besprozvannykh, Priamur'e..., op. cit.: 181-182, 188-191. On Shelikhov see D. Uspenskii, "Iz istorii russkikh snoshenii s narodami Vostoka," Russkaia mysl'(April 1904): 55-68, here 64-68, and L. Sitnikov, Grigorii Shelikhov (Irkutsk, 1990): 162-190. 
failure of the first attempt to begin negotiations with the Japanese shogunate in Edo (Tokyo). The decision to repatriate a number of Japanese merchants rescued on one of the Aleutian islands provided an opportunity to send a mission headed by Adam Laksman at the end of 1791 - when Iakobi had already left Irkutsk - a short while after the shogunate had ordered the destruction of foreign ships found in Japanese waters. The mission landed on Hokkaido, but the governor refused to let Laksman proceed to Edo, allowing him instead to sail on to Nagasaki, where he was again refused access to Edo in 1792.69 That year, we saw, China reopened the Kiakhta trade. Nevertheless, Russia's commercial prospects in the region remained dim.

Iakobi waxed enthusiastic about the prospects of Korean trade. He had been to Peking on a number of occasions, where he had met Korean traders who told him about the triangular Sino-Korean-Japanese trade. The eighteenth century was a time of peace and prosperity on the peninsula. There were substantial improvements in agricultural technology, with an emphasis on the production of cash crops. Wholesale commerce developed on a regional basis, involving Korean ginseng, Chinese silver, and Japanese copper, and many private merchants became very wealthy. Korean merchants lived in Peking in their own compound, next to that occupied by the Russian Ecclesiastical Mission. They told him about Korea's wealth in gold and silver, lead, iron, and precious stones, especially topaz. Chinese merchants made substantial profits reselling Russian goods such as tin dishes, soft leather (iuft), cloth, lambskins and saiga antlers. And wonders of wonders, there were crocodiles in the rivers and whales in the sea! Trading with Korea and Japan would stimulate trade with China, not in Kiakhta but in Canton and, across the Pacific, with California which, "according to Cook," was only 3000 kilometers from Petropavlovsk in Kamchatka. ${ }^{70}$

Obviously, Iakobi let his imagination run wild at the thought of the fantastic prospects which the acquisition of the Amur would open up for Russia and Eastern Siberia in particular. They certainly were well worth a war with China, if the Celestial empire refused to accept Russia's demands. But Iakobi must be forgiven for overlooking what had not yet become evident: that if the Asian Coastland was indeed the geographic periphery of the Heartland, economically, it was the core of East Asia, and Eastern Siberia but a distant periphery. In Iakobi's vision, the Coastland would eventually gravitate toward Eastern Siberia with its capital in Irkutsk and even in Urga. This was the vision of a Siberian landsman, awed by the majesty of the great rivers and the craggy slopes of the Heartland's periphery that steeply fell into the Coastland and at the sea shores, opening grand vistas into the

69. E. Fainberg, Russko-iaponskie otnosheniia..., op. cit.: 53-64; D. Uspenskii, "Iz istorii..," art. cit.: 58-59; "Popytki k zavedeniiu torgovli Rossii s Iaponiei v 1791 godu," Russkaia starina, 3 (July-Sept. 1896): 28-30. On Laksman's father (who brought back the Japanese from the Aleutians), see N. Raskin and I. Shafranovskii, Erik Gustavovich Laksman (Leningrad, 1971). Erik came from Finland and became a well-known botanist in Siberia.

70. "Nachertanie": 70, 77-78; K. Lee, A new history of Korea (Cambridge, MA, 1984): 223, 228-232. A saiga was an antelope of the steppe; saiga antlers were considered an aphrodisiac. 
beckoning world of the "East." But the East was far richer, and needed not much else beside Siberian raw materials (furs and forest products), while the Russians needed the foodstuffs and manufactured products which China and Japan, if not Korea, already produced in abundance. Entering the commercial world of the Coastland would inevitably expose the Russians to centrifugal economic forces pulling the peripheral provinces of Eastern Siberia, not deeper into the continent to create an integrated Siberian economic region, but outward toward the great markets of Northern and Southern Asia, with all the attendant political implications for Petersburg's hold over these provinces. The stress between an unrealistic vision of Russia's greatness in the Northern Pacific, a depressing realization of Siberia's backwardness, and an obsessive fear of losing political control over a periphery whose integration into the Coastland economy could alone pull out of its backwardness, would continue to characterize Russia's Far Eastern policy until our own day.

Iakobi's proposal to make war on China was only one of a number of recommendations by members of the ruling elite to get tough on a powerful China, ${ }^{71}$ which looked upon the Russians as another kind of barbarians from the steppes, toward whom it was necessary to keep the high ground of moral superiority, as befitted the Middle Kingdom at the center of the universe. The Russians, who themselves liked to think they occupied the political center of the Heartland, resented Chinese assumptions of political, moral, and strategic superiority in the vast Russo-Chinese frontier, which their advance across Siberia had created in the seventeenth century. Much of the resulting tension between the two hegemonic powers focused on the control of the frontier, in the Kazakh steppe, in Mongolia and in Northern Manchuria.

That proposal was unrealistic for three reasons: it was based on insufficient geographical knowledge of the frontier; it was driven by expectations of commercial rewards which neither the geopolitical situation in northern Asia nor Russian economic potential could possibly justify; and it would have required a radical change in Russia's strategic posture in the Eastern theater. During Catherine II's reign, a reorientation of Russian military policy did in fact take place, from an emphasis on the Western (chiefly Baltic) theater to the Southern (Black Sea) theater. The architect of that policy change, Grigorii Potemkin, was after 1774 until his death in 1791 the leading figure in Catherine's government in the field of foreign and military policy: not only was he the empress's morganatic husband, he was also the chief of the College of War and her proconsul in the Southern frontier.

71. Another such recommendation was made by Vladislav Raguzinskii in 1731: on the one hand, it would not pay to make war on China; on the other, if the Russian government could accumulate a sufficiently large budgetary surplus, it might want to take the risk and conquer (zavladet') the 200 million Chinese who suffered under the Manchu yoke, N. Bantysh-Kamenskii, Diplomaticheskoe sobranie..., op. cit.: 373-375. 
The new policy aimed at hegemony in the Black Sea basin and sought to establish a foothold in Transcaucasia, from which to strike at the Ottomans and the Persians. Russia did not have the resources to extend that costly policy to the Eastern theater, where enormous distances, inhospitable terrain and climate, and inadequate local resources, combined to make a hostile policy toward Manchu China at the height of its power a highly risky undertaking at best, particularly at a time when Russia was gearing up for the long struggle with Revolutionary France for control of the Central European frontier.

Davis Center for Russian Studies

Harvard University

652 Massachussetts Avenue

Cambridge

Massachussetts 02139

jledonne@fas.harvard.edu 